\title{
KEBIJAKAN DAN STRATEGI PENGATURAN USAHA PERIKANAN DAN PENGELOLAAN WILAYAH PESISIR DI TELUK JAKARTA YANG MENGACU PADA KEARIFAN LOKAL MASYARAKAT NELAYAN TRADISIONAL ${ }^{1}$
}

\author{
Afdol, M. Sofyan Pulungan, dan Bono B. Priambodo ${ }^{2}$
}

\begin{abstract}
Government's policies and regulations both at national and local level i.e. Government of Jakarta nowadays are thought to have positive as well as negative impacts on the lives and livelihood of traditional fishing communities along Jakarta Bay's shoreline. On the other hand, these communities also have their own perceptions, knowledges, and aspirations about their living space and environment, that are thought to have formed a distinct knowledge system known as the local wisdom. Pertaining to legal provision to acknowledge, respect and protect local wisdom possessed by adat (customary) communities that has been inherited from generation to generation, and thus referred to in coastal resources management. This research attempts to propose policies and regulations regarding natural and environmental resources management in Jakarta Bay shoreline that use the local wisdom of fishing communities that live there and depend on the resources for their lives as the main consideration and reference.
\end{abstract}

Keywords: policies and regulations, local wisdom, traditional fishing communities, Teluk Jakarta

\begin{abstract}
Abstrak
Kebijakan dan regulasi Pemerintah Pusat dan Pemerintah Daerah DKI Jakarta dewasa ini ditengarai berpengaruh baik positif maupun negatif pada kehidupan dan mata pencaharian komunitas-komunitas nelayan tradisional di sepanjang pesisir Teluk Jakarta. Di lain pihak, komunitas-komunitas itu memiliki persepsi, pengetahuan, dan aspirasinya sendiri mengenai lingkungan tempat tinggal dan lingkungan hidup mereka, yang diperkirakan telah membentuk suatu sistem pengetahuan tersendiri yang khas berupa kearifan lokal. Terkait dengan ketentuan hukum mengenai kearifan lokal masyarakat adat yang diwariskan secara turun-temurun harus diakui, dihormati, dan

${ }^{1}$ Artikel ini adalah Resume dari Hasil Riset Unggulan Universitas Indonesia Tahun 2008 yang dibiayai oleh Universitas Indonesia. Para penulis mengucapkan terima kasih kepada Untung Kusyono, Gunadi, Imang dan Dedy Nurhidayat yang telah membantu mencari dan pengelola data penelitian ini.

${ }^{2}$ Ketiga Penulis adalah Staf Pengajar Fakultas Hukum Universitas Indonesia. Alamat kontak: m_sofyan_p@yahoo.com.
\end{abstract}


dilindungi, bahkan dijadikan acuan dalam pengelolaan sumberdaya pesisir. Penelitian ini berupaya mengusulkan kebijakan dan regulasi pemerintah terkait sumberdaya alam dan lingkungan di pesisir Teluk Jakarta dengan menjadikan kearifan lokal komunitas-komunitas nelayan yang tinggal dan mencari hidup di sana sebagai bahan pertimbangan dan bahan acuan utama.

Kata kunci: Kebijakan dan Regulasi, Kearifan Lokal, Nelayan Tradisional, Teluk Jakarta

\section{Pendahuluan}

\section{Latar Belakang}

Paradigma kebijakan pembangunan kelautan dan perikanan nasional Indonesia dewasa ini telah mengintroduksi dan mengadopsi arti penting pengakuan dan perlindungan hukum nasional terhadap hukum adat dan/atau kearifan lokal yang hidup di tengah-tengah masyarakat pesisir dan masyarakat nelayan tradisional. Hal ini tampak dalam UU Nomor 31 Tahun 2004 tentang Perikanan. Pasal 6 Ayat (2) yang menegaskan bahwa pengelolaan perikanan untuk kepentingan penangkapan ikan dan pembudidayaan ikan harus mempertimbangkan hukum adat dan/atau kearifan lokal serta memperhatikan peran serta masyarakat. Lebih jauh lagi, UU Nomor 27 Tahun 2007 tentang Pengelolaan Wilayah Pesisir dan Pulau-pulau Kecil telah merintis pengaturan secara menyeluruh dan terpadu mengenai pelibatan dan keterlibatan masyarakat pesisir dan masyarakat nelayan tradisional dalam pengelolaan sumberdaya pesisir dan pulau-pulau kecil. Pasal 61 Ayat (2), misalnya, menegaskan bahwa kearifan lokal masyarakat adat yang diwariskan secara turun-temurun diakui, dihormati, dan dilindungi, bahkan dijadikan acuan dalam pengelolaan sumberdaya pesisir dan pulau-pulau kecil yang berkelanjutan.

Implementasi dari berbagai peraturan-peraturan yang menjadikan kearifan lokal dalam pengelolaan wilayah persisir, sepertinya belum menjadi acuan Pemerintah atau pemerintah daerah sampai saat ini. Di DKI Jakarta, dimana komunitas-komunitas nelayan tradisional bermukim di sepanjang pesisir Teluk Jakarta, hidup dalam kecemasan apakah komunitas nelayan tradisional masih akan eksis dalam beberapa tahun ke depan. Kecemasan ini muncul dari tekanan yang sangat kuat dari globalisasi dan urbanisasi bagi komunitas mereka melalui berbagai kebijakan dalam bentuk berbagai peraturan perundang-undangan yang selama ini telah dibuat oleh Pemerintah dan Pemerintah Daerah DKI Jakarta.

Salah satu kebijakan yang sangat mempengaruhi kehidupan masyarakat nelayan saat ini adalah implementasi dari kebijakan reklamasi daerah pesisir Teluk Jakarta. Reklamasi yang membentang sepanjang 32 kilometer, dari perbatasan Cilincing dan Bekasi hingga ke 
perbatasan Penjaringan dan Tangerang. Di lahan baru hasil reklamasi tersebut selain diperuntukkan bagi pembangunan kawasan komersial berupa industri, fasilitas kegiatan pariwisata, perkantoran, dan transportasi, akan dibangun pula kompleks perumahan mewah berkapasitas 750.000 jiwa. Proyek Reklamasi Pesisir Teluk Jakarta diperkirakan akan menggusur $25.000 \mathrm{KK}$ (Kepala Keluarga) atau sekitar 125.000 jiwa (walhi, 2006), dimana nelayan tradisional dan keluarganya yang masih hidup dalam kemiskinan dari generasi ke generasi telah ada disana dan menggantungkan hidup padanya sumberdaya alam wilayah persisir Teluk Jakarta.

\section{Pokok Permasalahan}

1. Kebijakan dan regulasi pemerintah pusat dan pemerintah daerah apa saja yang berpengaruh baik positif maupun negatif pada kehidupan dan mata pencaharian komunitas-komunitas nelayan tradisional di sepanjang pesisir Teluk Jakarta?

2. Bagaimanakah persepsi, pengetahuan, dan aspirasi komunitaskomunitas nelayan itu sendiri tentang lingkungan tempat tinggal dan lingkungan hidup mereka di sepanjang pesisir Teluk Jakarta, apakah persepsi, pengetahuan, dan aspirasi itu membentuk suatu sistem pengetahuan tersendiri yang khas berupa kearifan lokal?

3. Bagaimana seharusnya kebijakan dan regulasi pemerintah terkait sumberdaya alam dan lingkungan pesisir Teluk Jakarta jika kearifan lokal komunitas-komunitas nelayan yang tinggal dan mencari hidup di sana menjadi bahan pertimbangan dan bahan acuan?

\section{Tinjauan Litelatur}

Soto memahami istilah "pengetahuan tradisional" atau "kearifan lokal" sebagai pengetahuan yang didapatkan melalui pengalaman hidup di suatu tempat tertentu terkait hubungan manusia dengan lingkungannya sebagai suatu pengetahuan 'ekologis' dalam arti luas. ${ }^{3}$ Pengertian "tradisional" dalam konteks ini secara umum merujuk pada suatu badan pengetahuan, praktik, dan kepercayaan yang ditularkan secara kultural antar-generasi. Pengetahuan semacam ini merupakan produk kesinambungan historis pemanfaatan sumberdaya alam di suatu tempat tertentu. Apabila terjadi interaksi terusmenerus antara manusia dan lingkungan, pengetahuan pun terus dihasilkan, dievaluasi, dan dikomunikasikan secara dinamis.

${ }^{3}$ Soto, C.G., Socio-Cultural Barriers to Applying Fishers' Knowledge in Fisheries Management: An Evaluation of Literature Cases, Ph.D Dissertation in the School of Environmental Management Simon Fraser University, Burnaby, BC, Canada, 2006, hal. 34. 
Van Kerkhoff dan Lebel mengaitkan pentingnya kearifan lokal dalam peningkatan partisipasi publik untuk menghasilkan keputusan dan tindakan pengelolaan sumberdaya alam dan lingkungan yang lebih berkelanjutan karena alasan-alasan berikut. ${ }^{4}$ Pertama, menggali perspektif alternatif yang tidak dapat dicapai melalui cara-cara konvensional dalam memahami masalahmasalah yang khas. Kedua, menggalang dukungan terhadap keputusan yang diambil untuk mengatasi masalah bersama dan menyelesaikan sengketa yang timbul. Ketiga, memobilisasi sumberdaya dan membagi tanggung-jawab pengelolaan dalam tindakan-tindakan yang diambil. Keempat, mengembangkan kelembagaan yang mampu meningkatkan kapasitas masyarakat. Secara singkat, melalui pendekatan partisipatif ini, pengelolaan sumberdaya alam akan lebih berkelanjutan tidak saja secara ekologis, tetapi juga secara sosial dan ekonomi.

Decoster and Garcés menekankan bahwa pelaksanaan pendekatan berbasis ekosistem harus memfasilitasi dan memperkuat kearifan lokal masyarakat nelayan tradisional. ${ }^{5}$ Pada kenyataannya, pendekatan ini baru optimal jika ditujukan semata-mata pada pemberdayaan nelayan tradisional. Berdasarkan kearifan lokalnya, nelayan tradisional pasti akan mencegah siapapun melakukan praktik penangkapan ikan yang merusak stok ikan, habitat, dan tentu saja mata pencahariannya. Strategi potensial yang dapat ditempuh pemerintah adalah secara bertahap mengurangi operasi perikanan industri skala besar yang tidak saja terbukti merusak, tetapi juga memaksa nelayan tradisional untuk meninggalkan kearifan lokalnya karena persaingan yang tidak seimbang itu.

Walter dalam kaitannya dengan kearifan lokal menekankan arti penting fungsi kepenjagaan (stewardship) dalam manajemen sumberdaya alam berbasis komunitas. ${ }^{6}$ Masyarakat nelayan di kawasan pesisir percaya bahwa mereka ditugaskan untuk "menjaga" sumberdaya ikan dan mengelolanya agar tetap lestari sampai ke anak cucu. Apabila masyarakat dibiarkan tetap menjalankan tugas kepenjagaannya, anggota-anggota masyarakat akan dengan sukarela menegakkan sistem yang fundamental bagi nilai-nilai yang dianut dan dihormati oleh komunitasnya itu. Selain itu, peningkatan kendali komunitas atas sumberdaya juga akan meningkatkan keadilan ekonomi dan pemerataan kesejahteraan, yang harus dibarengi dengan upaya menghentikan konsolidasi kepemilikan perorangan atas akses kepada sumberdaya, jika tidak atas sumberdaya itu sendiri.

${ }^{4}$ L.v. Kerkhoff, and Lebel, L., Linking Knowledge and Action for Sustainable Development, Annual Review of Environment and Resources Volume 31 (2006), hal. 14.

5 J. Decoster, and Garcés, P.A. (eds.), "Challenges Facing Artisan Fishery in the 21st Century”, (Bangalore: Pipal Tree, 2001), hal. 28.

${ }^{6}$ E. Walter, Fishing Around the Law: The Pacific Salmon Management System as a "Structural Infringement" of Aboriginal Rights, McGill Law Journal, Volume 45 (2000), hal. 55. 
Eghenter, Sellato, dan Devung menyatakan keberhasilan pengelolaan sumberdaya alam yang berkelanjutan sangat bergantung pada lestarinya nilainilai budaya lokal, terutama yang terkait dengan praktik-praktik tradisional pengelolaan sumberdaya alam. ${ }^{7}$ Secara spesifik, pengetahuan dan persepsi masyarakat dan sikapnya terhadap lingkungan alam harus diidentifikasi, demikian juga dengan interaksi antara manusia dan alam sekitarnya dari masa ke masa. Nilai-nilai tradisional mengenai pengelolaan sumberdaya alam secara berkelanjutan, yang sudah ditinggalkan karena desakan modernitas digali kembali dan disesuaikan dengan kondisi mutakhir.

Dewasa ini, pendekatan manajemen bersama (co-management) atau manajemen terpadu (integrated management) yang merupakan bentuk partisipatif dari manajemen yang melibatkan banyak pemangku kepentingan (stakeholder) dalam suatu kerangka spasial tertentu semakin banyak dianut dalam pengelolaan sumberdaya pesisir di berbagai belahan dunia. Dalam rangka membangun kapasitas, kepercayaan, kepercayadirian, dan suasana saling menghormati di antara pemangku kepentingan, pengetahuan nelayan tradisional sebagai sebuah bentuk pengetahuan yang dinamis berpotensi besar dalam merumuskan tujuan-tujuan konkrit pengelolaan modern. Oleh karena itu, semua pemangku kepentingan harus bersama-sama mengkaji dan mendisain atau mengadaptasi lembaga-lembaga yang akan membangkitkan dan memperkuat potensi keterlibatan nelayan baik sebagai pengambil keputusan maupun pemilik pengetahuan. Namun, kemitraan antar-pemangku-kepentingan tidak akan mencapai hasil optimal jika pembagian hak dan tanggung-jawab tidak sepenuhnya mencerminkan kepentingan dan aspirasi pihak-pihak yang terlibat. $^{8}$

\section{Metode Riset}

\section{Asumsi dan Batas-Batas Penelitian}

Asumsi yang digunakan adalah asumsi yuridis-normatif bahwa kearifan lokal masyarakat adat yang diwariskan secara turun-temurun harus diakui, dihormati, dan dilindungi, bahkan dijadikan acuan dalam pengelolaan sumberdaya pesisir yang berkelanjutan. Di samping itu, kearifan lokal masyarakat nelayan tradisional yang sepenuhnya menggantungkan hidup pada sumberdaya alam dan lingkungan pesisir Teluk Jakarta diasumsikan - jika digunakan sebagai acuan utama penyusunan kebijakan dan regulasi terhadapnya - akan lebih

${ }^{7}$ Eghenter, C., Sellato, B., and Devung, G.S. (Ed.), "Social Science Research and Conservation Management in the Interior of Borneo, Unravelling Past and Present Interaction of People and Forest", (Bogor: Center for International Forestry Research (CIFOR), 2003), hal. 68 .

${ }^{8}$ Soto, C.G., Op. Cit., hal. 88. 
berkelanjutan tidak saja secara sosial ekonomi tetapi juga ekologis, jika dibandingkan dengan penaksiran bisnis semata.

Penelitian ini ingin menggali pengetahuan mengenai praktik kebiasaan dan kepercayaan yang dimiliki oleh komunitas-komunitas nelayan di pesisir Teluk Jakarta, yang secara keseluruhan membentuk kearifan lokal dalam memanfaatkan, mengelola, dan menjaga kelestarian sumberdaya alam dan lingkungan demi keberlanjutan mata pencaharian dan hidupnya. Walaupun banyak dari mereka adalah warga pendatang dari daerah-daerah lain di sepanjang pesisir pantai utara Jawa dan wilayah-wilayah lain yang memang terkenal akan budaya maritimnya seperti Bugis dan Madura, pada umumnya telah lama tinggal dan menetap di pesisir Teluk Jakarta dari generasi ke generasi. Interaksi antar masyarakat yang didasarkan atas berbagai budaya masyarakat nelayan, telah menimbulkan statu perpaduan bentuk kearifan lokal yang unik dan khas bagi nelayan urban di Jakarta. Penelitian ini dilaksanakan di 2 (dua) kecamatan di wilayah administrasi Kota Jakarta Utara yang diperkirakan paling signifikan kegiatan dan persentuhan penduduknya terkait dengan pemanfaatan sumberdaya pesisir dan perikanan, yaitu Kecamatan Penjaringan dan Kecamatan Cilincing.

\section{Pendekatan dan Metode}

Pendekatan socio-legal digunakan dalam penelitian ini dengan tujuan untuk mengetahui keberlakuan hukum dalam masyarakat. Hukum yang dimaksudkan dalam penelitian ini tidak hanya produk hukum dan regulasi yang dibuat oleh institusi-institusi resmi Negara/Pemerintah, namun juga hukum tidak tertulis berupa kearifan lokal yang hidup ditengah-tengah masyarakat. Pendekatan socio-legal dalam penelitian ini akan sangat bermanfat untuk mengetahui bagaimana keberlakuan dan efektifitas kebijakan Negara dalam bentuk aturan hukum yang lahir akibat pengaruh globalisasi dan urbanisasi bagi masyarakat nelayan tradisional di teluk Jakarta. Metode penelitian yang digunakan dalam penelitian ini adalah metode kualitatif. Dengan menggunakan metode kualitatif, penelitian ini akan mengeksplorasi pengalaman dan penilaian manusia yang menjadi objek penelitian tentang pandangan hidup, nilai, harapan, kenyakinan dan konsep-konsep subjektif lainnya.

Data dalam penelitian ini berupa data primer dan data sekunder. Pengumpulan data primer dilakukan melalui focus group discussion (FGD) dan juga didukung dengan wawancara yang mendalam (deep interview) secara langsung dengan komunitas-komunitas nelayan tradisional di teluk Jakarta yang berdomisili di kecamatan Penjaringan dan Cilincing Kotamadya Jakarta Utara. Selain itu, pengumpulan data juga dilakukan dengan observasi secara langsung peneliti terhadap kehidupan keseharian masyarakat nelayan tradisional di dua kecamatan tersebut. Sedangkan pengumpulan data sekunder dari penelitian dilakukan dengan mengumpulkan data-data hukum berupa kebijakan- 
kebijakan Negara/Pemerintah dalam bentuk Undang-Undang, Peraturan Pemerintah, Keputusan Presiden, Keputusan Menteri dan Peraturan Daerah DKI Jakarta yang terkait dengan objek penelitian. Selanjutkan, data-data non hukum akan diperoleh dari buku, jurnal, makalah, data statistik, dan kliping berita dari media massa yang merekam kehidupan, konflik dan dinamika masyarakat nelayan tradisional teluk Jakarta.

\section{Hasil dan Temuan}

\section{Analisis Terhadap Peraturan Perundang-Undangan Terkait}

Penelitian ini pertama-tama melakukan analisis hukum terhadap berbagai peraturan perundang-undangan formal yang terkait dengan usaha perikanan dan pengelolaan wilayah persisir baik di tingkat nasional maupun peraturan di tingkat lokal. Peraturan-peraturan tingkat nasional yang dianalisis diantaranya; UU Nomor 31 Tahun 2004 tentang Perikanan, UU Nomor 27 Tahun 2007 tentang Pengelolaan Wilayah Pesisir dan Pulau-pulau Kecil, Keppres Nomor 52 Tahun 1995 tentang Reklamasi Pantai Utara Jakarta, Perpres Nomor 54 Tahun 2008 tentang Penataan Ruang Kawasan Jakarta, Bogor, Depok, Tangerang, Bekasi, Puncak, Cianjur, Keputusan Menteri Negara Lingkungan Hidup Nomor 14 Tahun 2003 tentang Ketidaklayakan Rencana Kegiatan Reklamasi dan Revitalisasi Pantura.

Sedangkan peraturan tingkat lokal yang dianalisis diantaranya; Peraturan daerah (Perda) DKI Jakarta No. 8 Tahun 1995 tentang Penyelenggaraan Reklamasi dan Rencana Tata. Ruang Kawasan Pantai Utara Jakarta, Keputusan Gubernur KDKI Jakarta Nomor 972 Tahun 1995 tentang Pembentukan Organisasi dan Tatakerja Badan Pelaksana Reklamasi Pantura Jakarta, Keputusan Gubernur KDKI Jakarta Nomor 1090 Tahun 1996 tentang Organisasi dan Tatakerja Badan Pengendali Reklamasi Pantura Jakarta, dan Keputusan Gubernur DKI Jakarta Nomor 138 Tahun 2000 tentang Tata cara penyelenggaraan Reklamasi Pantai Utara Jakarta.

Hasil analisis terhadap peraturan perundang-undangan terkait adalah Pertama, telah terjadi inkonsistensi pengaturan di tiap tingkat. Legislasi tingkat nasional mengadopsi pedoman internasional tentang pengakuan masyarakat nelayan tradisional, hak mereka atas sumberdaya pesisir dan kearifan lokalnya. Sedangkan peraturan pelaksanaan baik di tingkat nasional maupun lokal masih menggunakan paradigma lama, yaitu pendekatan teknokratis developmentalis yang bersifat top-down. Kedua, masih kuatnya ego sektoral (departemen) dalam pengaturan teluk Jakarta, akibatnya setiap sektor akan memperjuangkan kepentingan masingmasing sehingga kerjasama antar sektor hanya akan dijalin jika terdapat garansi bahwa kepentingan unit kerja mereka turut diamankan. Dengan kata lain, kuatnya ego sektoral telah menumpulkan upaya-upaya 
koordinasi dan sinkronisasi kebijakan pengelolaan sumberdaya ekonomi dengan lingkungan belum terwujud.

\section{Tekanan Globalisasi dan Urbanisasi}

Berbagai peraturan diatas muncul sebagai refleksi dari tekanan globalisasi dan urbanisasi disektor perikanan dan pengelolahan wilayah persisir di Teluk Jakarta. Tekanan globalisasi terlihat dari; Pertama, ambiguitas tujuan pengaturan, yaitu; tujuan peningkatan ekspor komoditas perikanan tidak mungkin diselaraskan dengan tujuan pengentasan kemiskinan masyarakat nelayan tradisional dan budidaya perikanan, munculnya dilema pertumbuhan vis a vis pemerataan. Kedua, benturan antar-skala ekonomi usaha perikanan, yaitu; tidak ada demarkasi yang jelas antara perikanan industri baik menengah maupun besar, dan perikanan skala kecil, dan tradisional. Sektor perikanan dengan skala berbasis industri tentu saja diuntungkan. Sedangkan tekanan urbanisasi, pertama, benturan modal produksi perkotaan dan pedesaan, modal produksi urban yang padat modal, padat teknologi, dan akhirnya padat polusi, meminggirkan modal produksi rural yang sangat bergantung pada kualitas sumberdaya lingkungan. Kedua, Stigma Sosial tentang Kaum Miskin Kota, yaitu pandangan bahwa Nelayan urban tidak ubahnya kaum miskin kota lainnya yang merusak keindahan kota. Proyek reklamasi pantai yang telah menjadi trend kota-kota metropolitan dunia dianggap solusi untuk menata kawasan pantai kota dan mengatasi keterbatasan wilayah kota Jakarta.

\section{Kearifan Lokal}

Kearifan lokal (local wisdom) sangat erat kaitannya dengan pengelolaan sumberdaya alam secara berkelanjutan. Kearifan lokal menekankan arti penting fungsi kepenjagaan (stewardship) dalam manajemen sumberdaya alam berbasis komunitas. Berikut ini adalah beberapa bentuk kearifan lokal yang masih ditemui di nelayan tradisional Teluk Jakarta.

\section{a. Segi Sosial Budaya}

Dalam konteks sosial budaya, masyarakat nelayan tradisional adalah masyarakat yang bangga akan identitas, keterampilan dan pengetahuan khusus yang mereka miliki, yang diwariskan secara turun-temurun. Masyarakat nelayan merasa bahwa laut "diamanatkan" oleh Tuhan kepada mereka secara bersama-sama, oleh karena itu merasa berkewajiban untuk menjaganya bagi kehidupan seluruhnya. Ikatan sosial sebagai nelayan telah melahirkan suatu kearifan lokal yang selalu menjunjung tinggi model-model penyelesaian masalah dengan mengutamakan musyawarah untuk mencapai mufakat. Acara sedekah laut (nyadran) 
tidak hanya dijadikan sebagai umgkapan syukur atas hasil ikan yang telah diperoleh, namun juga berfungsi sangat penting dalam menjaga hubungan persaudaraan antar nelayan agar bersatu menjaga kelestarian. Persaingan terbuka diantara sesama nelayan tradisional dengan nelayan tradisional yang lain juga tidak ditemukan. Hal ini didasarkan atas kepercayaan mereka bahwa laut adalah milik bersama, sedangkan hasil tangkapan adalah tergantung kemampuan masing-masing individu dalam mencari dan menangkap ikan yang ada dilaut.

\section{b. Segi Sosial Ekonomi}

Sebagian besar kandungan kearifan lokal masyarakat nelayan dari segi sosial ekonomi adalah mengenai teknologi perikanan yang tepat-guna dan sangat ramah lingkungan, meski untuk standar industri modern sangat sederhana. Teknologi itu digunakan untuk menjalani kehidupan yang sifatnya semi-subsisten, tetapi ramah lingkungan dan berkelanjutan terkait dengan etos kepenjagaan (stewardship) nelayan terhadap lingkungan sumberdayanya. Sejalan dengan itu, satuan-satuan ekonomi nelayan tradisional pun sangat sederhana, didasarkan atas kepercayaan (trust) dan persaudaraan (brotherhood/sisterhood), dengan minimal bersentuan ke pasar modern. Kearifan lokal dalam menjaga lingkungan sangat bersentuan terhadap sumber mata pencarian. Bagi masyarakat persisir, kawasan mangrove merupakan sumber mata pencaharian masyarakat, terutama produk kerang dan ketam (kepiting). Sehingga bagi nelayan tradisional Teluk Jakarta pelestarian hutan bakau tidak saja untuk mencegah banjir dan mencegah kerusakan ekosistem dikawasan tersebut, namun juga untuk mencegah dampak ekonomi yang dimunculkan, yaitu menurun atau hilangnya sumber mata pencarian alternatif nelayan.

\section{c. Segi Sosial Lingkungan}

Kearifan lokal dalam segi sosial lingkungan didasarkan pada pengetahuan masyarakat bahwa tingkat kualitas lingkungan sumberdaya laut pesisir tertentu dibutuhkan untuk menyelenggarakan usaha perikanan yang berkelanjutan bagi penghidupan mereka. Pertumbuhan kota yang pesat dan tidak berkelanjutan merupakan penyebab utama kerusakan lingkungan sumberdaya laut dan pesisir. Pengetahuan dan kemampuan mereka, walaupun masih bersifat tradisional, terbukti mampu dan dapat dipergunakan dengan baik sesuai dengan kebutuhan mereka dan kebutuhan untuk melestarikan alam. Pandangan berpikir yang mereka gunakan adalah ekosistem kehidupan laut dan pemanfaatannya sebagai sumber bagi kehidupan masyarakat nelayan harus diwariskan kepada generasi-generasi selanjutnya. Pandang ini, berdasarkan asumi dasar yang mereka 
gunakan bahwa menjadi nelayan adalah tradisi keluarga yang dilakukan secara turun-menurun. Bagi mereka, laut tidak sematamata merupakan sebuah sistem ekologi, tetapi juga sistem sosial. Data yang diperoleh dari 35 nelayan tradisional yang menjadi informan, 30 nelayan tersebut berasal dari orang tua yang dahulunya juga nelayan sedangkan 5 nelayan memiliki hubungan persaudaraan jauh. Data di atas menunjukan alasan yang sangat logis mengapa nelayan tradisional sangat sadar sepenuhnya untuk menjaga laut dan seluruh ekosistem demi kelanjutan antar generasi.

\section{Analisis Kearifan Lokal}

Secara umum kandungan kearifan lokal nelayan Teluk Jakarta tidak jauh berbeda dengan komunitas nelayan tradisional manapun di seluruh Indonesia. Akan tetapi, yang paling penting adalah pengetahuan mereka mengenai tekanan-tekanan globalisasi dan urbanisasi yang dialami sebagai masyarakat nelayan tradisional yang hidup tepat di pinggiran megapolitan Jakarta yang terus bertumbuh pesat. Strategi adaptasi mereka dengan konteks urban merupakan bahan pengetahuan yang sangat berharga. Tekanan-tekanan kronis yang mereka alami membuat konstruksi kearifan lokal tersebut telah mengalami erosi yang sangat parah. Atas dasar inilah, harus dilakukan tindakan afirmatif yang lebih kuat dalam bentuk kebijakan dan pengaturan yang digunakan agar kelestarian kearifan lokal masyarakat nelayan dapat terjaga.

\section{Kebijakan dan Strategi Pengaturan}

\section{Pengukuhan Satuan-satuan Ekonomi Tradisional Masyarakat Nelayan Teluk Jakarta Menjadi Koperasi Nelayan}

Upaya pengentasan kemiskinan melalui prakarsa masyarakat setempat lebih menegaskan pencapaian keberhasilan, yang disandarkan pada semangat untuk memelihara dan meningkatkan harkat kemanusiaan? (Loxley, 2000). Hasil studi lapangan penelitian ini mengungkapkan berbagai permasalahan yang muncul akibat tekanan globalisasi dan urbanisasi telah meminggirkan dan bila tidak dilakukan kebijakan keras bahkan akan memberangus keberadaan komunitaskomunitas nelayan tradisional di Teluk Jakarta. Di sinilah hakikat dari permasalahan "nelayan urban" yang menjadi fokus penelitian ini. Pertanyaan paling mendasar yang harus dijawab oleh semua pemangku kepentingan yang terkait adalah: Apakah harkat kemanusiaan mereka

9 Loxley. "Aboriginal Economic Development in Winnipeg", dalam Silver (ed.). Solutions That Work. Fighting Poverty in Winnipeg, (Winnipeg: Canadian Centre for Policy Alternatives, 2000), hal. 91. 
patut dipelihara bahkan ditingkatkan? Atas dasar ini suatu pendekatan pemberdayaan ekonomi lokal yang memadukan program-program produksi, konsumsi barang dan jasa dan penanaman kembali modal yang terhimpun harus dirancangkan dan ditempuh.

Jika diletakkan dalam kerangka hukum, strategi pemberdayaan ekonomi lokal selayaknya didasarkan pada prinsip-prinsip yang sejiwa dengan cita-cita koperasi sebagaimana termaktub dalam Pasal 33 UUD 1945, yang juga diharapkan menjadi corak usaha dan pengelolaan sumberdaya alam Indonesia pada umumnya. Sebagai suatu badan usaha, koperasi adalah badan sosial-ekonomi untuk "menolong diri sendiri secara bersama-sama," yang dapat didirikan atas inisiatif bersama masyarakat sebagai bentuk pemberdayaan diri (self-empowerment) atau ditumbuhkan oleh pihak-pihak dari luar masyarakat sebagai agen-agen pembangunan (agents of development).

Dari temuan-temuan dari studi lapangan dapat disimpulkan bahwa prinsip dan semangat "menolong diri sendiri secara bersama-sama" sesungguhnya tertanam dalam sikap mental nelayan tradisional di Teluk Jakarta, sebagaimana juga nelayan tradisional pada umumnya. Hal ini terkait erat dengan lingkungan kehidupan dan pekerjaan mereka di tengah lautan yang keras dan penuh bahaya. Namun demikian, karena lingkungan kehidupan dan pekerjaan yang begitu jugalah, semangat tolong-menolong mereka juga terpupuk. Etos seperti ini juga terbawabawa sampai ke daratan, dan ketika mereka harus membentuk ikatan kerja sama satu sama lain, yang sesungguhnya merupakan satuan-satuan ekonomi tradisional meski sangat sederhana.

Satuan ekonomi ini dapat berupa ikatan antara pemilik kapal dan nakhoda beserta seluruh awaknya, atau sesama nelayan yang bersamasama membangun dan mengoperasikan alat tangkap tertentu, sampai dengan hubungan antara nelayan-nelayan dengan para perantara (middlemen) seperti juragan ikan. Dalam perspektif hukum, ikatan sosial yang sangat kuat untuk "menolong diri sendiri secara bersama-sama" dapat diwujudkan dengan mengusahakan suatu bentuk legal formal bagi satuan-satuan ekonomi tradisional yang selama ini dibentuk oleh nelayan-nelayan tersebut. Bentuk badan usaha yang paling sesuai yang dapat digunakan adalah badan hukum koperasi, dengan membentuk koperasi nelayan atau gabungan koperasi nelayan di teluk Jakarta.

Pilihan dari strategi ini memiliki tantangan dalam hal implimentasi. Tantangan ini adalah sikap skeptis dan putus asa komunitas-komunitas nelayan itu sendiri terhadap koperasi perikanan. Data lapangan kami, menyimpulkan tidak satupun nelayan yang menjadi responden percaya terhadap kelembagaan koperasi. Pandangan masyarakat ini muncul disebabkan keberadan koperasi perikanan yang lebih dikenal dengan sebutan Koperasi Unit Desa (KUD) Mina yang ada di teluk Jakarta tidak cukup mengembirakan di mata nelayan. Masalah-masalah internal koperasi perikanan seperti salah kelola, penyelewengan kredit untuk kepentingan pribadi dan kerabat pengelola, persyaratan administratif 
yang terlalu ketat menyebabkan nelayan kembali pada praktik-praktik tradisional yang melibatkan tengkulak dan rentenir, yang justru ingin diberantas oleh koperasi. Masalah eksternal berupa intervensi birokrasi ke dalam sistem sosio-kultural masyarakat nelayan yang pada umumnya lebih berjiwa mandiri ketimbang petani, memicu sikap resisten terhadap campur-tangan pemerintah yang berlebihan dan tidak mengindahkan padangan hidup dan tata nilai nelayan. ${ }^{10}$

\section{Integrasi Lembaga Ekonomi Masyarakat Nelayan Teluk Jakarta ke dalam Pengelolaan Infrastruktur dan Tata-niaga Usaha Perikanan}

Kemantapan institusional koperasi nelayan ataupun unit-unit ekonomi perikanan skala kecil sampai menengah lainnya sangat tergantung pada derajat integrasinya dengan pengelolaan infrastruktur perikanan dan tata-niaga komoditas perikanan. Pada dasarnya terdapat suatu hubungan positif di antara keduanya, di mana semakin terintegrasi unit-unit ekonomi tersebut ke dalam keseluruhan pengelolaan infrastruktur dan tata-niaga perikanan. Oleh karena itu, nasib koperasi nelayan sangat ditentukan kepada siapa hak pengelolaan atas infrastruktur dan tata-niaga itu diberikan oleh pemerintah. ${ }^{11}$ Pada kenyataannya, hampir semua pangkalan pendaratan ikan (PPI) dan tempat pelelangan ikan (TPI) di seluruh Indonesia dibangun dan, karena itu, dioperasikan oleh pemerintah, dalam hal ini pemerintah daerah setempat.

Dalam perkembangannya, tekanan globalisasi dalam hal kebijakan infrastruktur dan tata-niaga telah mengubah pendekatan lama dengan dengan mencoba menyerahkan tanggung-jawabnya untuk menyediakan dan memelihara infrastruktur perikanan kepada dunia usaha. Tentu saja, agar dunia usaha tertarik untuk mengambil-alih pekerjaan tersebut harus disediakan insentif-insentif tertentu. Hal pertama dan terutama yang harus dilakukan adalah jaminan "iklim usaha yang kondusif," yang dapat dipahami sebagai kemudahan dan keamanan investasi di sektor perikanan. Satu paket dengan hal tersebut adalah jaminan bahwa investasi itu dapat dikembangkan menjadi suatu industri sampai dengan skala yang sebesar-besarnya, sejalan dengan watak dunia usaha yang senantiasa berupaya memperbesar keuntungan dan modalnya. Jika sudah demikian, maka keberadaan usaha perikanan skala kecil yang menjadi sandaran hidup nelayan-nelayan tradisional dan pengrajin dalam posisi yang sulit. Seperti gelaja yang ditemukan dalam penelitian ini, fasilitas

${ }^{10}$ Kusnadi, ”Akar Kemiskinan Nelayan”, Cet. I. (Yogyakarta: LkiS, 2003), hal. 44.

${ }^{11}$ Soetrisno. "Wajah Koperasi Tani dan Nelayan di Indonesia: Sebuah Tinjauan Kritis." Jurnal Ekonomi Rakyat Tahun II (Nomor 5 Agustus 2003). <http://www.ekonomirakyat.org/ edisi_17/artikel_4.htm>, diakses tanggal 14 Januari 2004. 
infrastruktur perikanan di Jakarta terutama dinikmati oleh nelayannelayan "besar" sedangkan nelayan setempat lebih suka menciptakan secara swadaya infratstruktur-infrastruktur informal di kalangan mereka sendiri.

Pilihan strategi berdasarkan kacamata kearifan lokal masyarakat nelayan itu sendiri adalah mengintegrasikan lembaga ekonomi masyarakat nelayan ke dalam pengelolaan infrastruktur perikanan dan tata-niaga komoditas perikanan. Pengintegrasian ini adalah penghargaan dan pengakuan komunitas-komunitas nelayan tradisional oleh pemangkupemangku kepentingan yang terlibat dalam pemanfaatan kawasan usaha perikanan dan sumberdaya pesisir. Pemerintah harus kali pertama mempertegas posisi moralnya dalam hal ini, seperti pernyataan keberpihakan terhadap komunitas nelayan tradisional teluk Jakarta sampai dengan inisiatif kebijakan.

Selain itu, kiranya perlu juga dikembangkan suatu suasana saling pengertian di antara seluruh pemangku kepentingan kawasan pesisir, di mana tanggung-jawab pengelolaan kawasan pesisir harus dipikul secara bersama-sama. Mungkin etos dan sikap mental masyarakat nelayan tradisional yang menganggap laut sebagai amanat atau "titipan" Tuhan Yang Maha Esa yang harus mereka jaga dapat menjadi inspirasi bagi pemangku-pemangku kepentingan lainnya. Pemerintah sebagai pemegang kekuasaan publik sudah pada tempatnya untuk bersikap proaktif memberikan pengertian bahwa, misalnya, pengadaan dan pemeliharaan infrastruktur perikanan, pun masih berada dalam kerangka kepenjagaan (stewardship) terhadap laut sebagai amanat Tuhan. Lebih dari sekadar hitung-hitungan untung rugi pengadaan dan pemeliharaan infrastruktur perikanan, hal ini mensyaratkan kemauan untuk terlibat dalam proses saling belajar (learning process) di antara para pemangku kepentingan, sehingga suasana kebathinan atau kejiwaan sebagai sesama penjaga (steward) amanat dapat ditumbuhkan.

\section{Pembentukan Suaka Terpadu (Eco-socio-economic Sanctuary) di Wilayah Pesisir Teluk Jakarta.}

Pilihan strategi terakhir yang dapat ditempuh sekiranya institusionalisasi dan integrasi satuan-satuan ekonomi tradisional masyarakat nelayan Teluk Jakarta ke dalam manajemen infrastruktur perikanan dan tata-niaga usaha perikanan bukan merupakan pilihan yang tepat adalah pembentukan suaka laut (marine protected area; MPA atau marine sanctuary). Suaka laut ini pengelolaannya didasarkan atas pendekatan manajemen sumberdaya pesisir berbasis komunitas (community-based coastal resources management; CBCRM). Pendekatan ini terbukti jauh lebih manjur untuk mencapai tujuan-tujuan konservasi, karena keterlibatan masyarakat didalamnya justru menjadi penjaga (steward) dari sumberdaya bersangkutan. Suaka yang dikelola sendiri oleh masyarakat setempat sebagai bagian dari sosio-ekosistem 
lebih aman dari "tangan-tangan jahil" pihak-pihak yang berada di luar sistem itu. Lagipula, keberadaan masyarakat setempat yang dapat terus mengambil manfaat dari lingkungan dan sumberdayanya secara berkelanjutan, berimplikasi pada turut terlestarikannya cara hidup, budaya beserta segenap nilai-nilai yang dimiliki oleh masyarakat itu.

Filipina yang merupakan negara kepulauan (archipelagic), sama seperti Indonesia memiliki sejarah yang sangat panjang dalam menerapkan pendekatan manajemen sumberdaya pesisir berbasis masyarakat, khususnya yang berbentuk Suaka Laut Berbasis Masyarakat (SLBM). Proyek-proyek ini menerapkan konsep SLBM skala kecil pada program-program pengembangan dan pengelolaan masyarakat pesisir di mana suatu suaka laut merupakan tema utamanya atau merupakan bagian dari salah satu strateginya. Sehingga kini di seluruh Filipina setidaknya terdapat 439 suaka laut dari berbagai tipe, dengan SLBM skala kecil menjadi sejumlah terbesarnya. ${ }^{12}$

Akan tetapi, untuk menerapkan SLBM pada konteks Teluk Jakarta diperlukan beberapa penyesuaian di sana-sini. SLBM biasanya dikembangkan pada kawasan pesisir yang kaya akan terumbu karang, sedangkan pesisir Jakarta Utara khususnya merupakan ekosistem muara dan hutan bakau (mangrove). Terumbu karang dan padang lamun (dasar laut yang ditumbuhi rumput laut) dapat juga ditemukan dalam jumlah terbatas. Selain memiliki fungsi ekologis dan hidrologis yang sangat penting, ekosistem muara dan hutan bakau yang terpelihara ternyata dapat juga menjadi objek wisata lingkungan (ecotourism) yang berdayatarik tinggi. Hal ini tampak nyata, misalnya, di Sundarbans, Bangladesh sebagai salah satu hutan bakau terluas di dunia dan sudah dinyatakan sebagai situs warisan dunia (world heritage site).

Pada dasarnya, semua intevensi dan inisiatif pembangunan pernah dilakukan terhadap pesisir utara Jakarta kecuali perhatian yang tulus dan serius terhadap usaha konservasi lingkungan. Berbagai studi mengungkapkan bahwa laju kerusakan lingkungan di Jakarta sebagai pusat pertumbuhan jauh melampaui tempat-tempat lainnya di Indonesia. Dari sini saja seharusnya sudah cukup alasan untuk memberikan perhatian lebih kepada permasalahan lingkungan di Jakarta. Akan tetapi, perhatian lebih pada masalah lingkungan ini tidak lantas berarti menghentikan sama sekali kegiatan ekonomi di salah satu kawasan atau sektor ekonomi Jakarta. Pariwisata, misalnya, adalah salah satu sektor yang dapat memberikan sumbangan besar pada bidang ekonomi. Kenya dan Tanzania yang mengelola taman-taman safari kelas dunia mendapatkan pasokan utama devisanya dari kegiatan wisata mancanegara di taman-taman itu. Australia juga diakui sebagai inovator

${ }^{12}$ Crawford, B., Balgos, M., and Pagdilao, C.R. "Community-based Marine Sanctuaries in the Philippines: A Report on Focus Group Discussions", (Laguna: Coastal Resources Center, University of Rhode Island, Narragansett, RI and Philippine Council for Aquatic and Marine Research and Development, 2000), hal. 14. 
dalam industri pariwisata berbasis lingkungan, yang merupakan industri ekspor terbesar negara ini.

Pilihan strategi ini membutuhkan keberanian berinovasi khususnya dari pihak Pemerintah dan Pemda DKI Jakarta. Kegiatan ekonomi metropolitan yang membenturkan segala macam dan ragam sektor ekonomi, dari sektor-sektor tercanggih sampai sektor-sektor paling primitif, memang merupakan tantangan tersendiri. Relokasi industri dan perumahan merupakan wacana yang tidak boleh ditutup kemungkinannya, bahkan harus dibuka dengan cerdik dan penuh perhitungan matang. Peningkatkan kualitas sumberdaya lingkungan Teluk Jakarta sudah jelas tidak dapat dipisahkan dari tata-kelola sungaisungai yang mengalir membelah kota Jakarta beserta berbagai kegiatan ekonomi maupun domestik yang bertumbuhan di sepanjang bantarannya.

Tata ruang dan peruntukan lahan jika kebijakan ini dipilih, akan menjadi isu hukum yang paling krusial. Untuk menata wilayah persisir Teluk Jakarta menjadi suatu suaka terpadu diperlukan dukungan dan keterlibatan provinsi tetangga DKI Jakarta, yaitu; Jawa Barat dan Banten. Pengaturan secara khusus wilayah persisir teluk Jakarta memerlukan instrumen hukum yang kuat seperti setingkat Undang-undang atau Peraturan Presiden. Pilihan dari kebijakan dan pengaturan ini hanya bisa dijalankan bila ada political will dari Pemerintah. Impimentasi dari pilihan ini membutuhkan suatu kepemimpinan yang lebih peduli pada kualitas lingkungan hidup Jakarta dan keberpihakan kepada nelayan tradisional di wilayah persisir teluk Jakarta.

\section{Penutup}

\section{Kesimpulan}

Berbagai kebijakan dan regulasi baik oleh pemerintah pusat maupun pemerintah daerah berpengaruh baik positif maupun negatif pada kehidupan dan mata pencaharian komunitas-komunitas nelayan tradisional di sepanjang pesisir Teluk Jakarta. Secara umum, kebijakan di tingkat pusat, terlebih yang diberlakukan dalam waktu-waktu belakangan ini, sudah menunjukkan perhatian yang lebih baik pada permasalahan komunitas nelayan tradisional, bahkan memberikan pengakuan dan jaminan hukum tidak saja bagi keberadaannya tetapi juga pada kearifan lokal yang mereka miliki. Sayangnya, beberapa peraturan baik di tingkat pelaksanaan maupun daerah, terlebih yang telah berlaku sejak lama, masih menggunakan pendekatan konvensional yang menitikberatkan pada kontribusi ekonomi semata tanpa memperhatikan aspek-aspek ekologis dan sosio-kultural yang lebih luas.

Komunitas-komunitas nelayan Teluk Jakarta memiliki persepsi, pengetahuan, dan aspirasi yang khas tentang lingkungan tempat tinggal dan lingkungan hidup mereka di sepanjang pesisir Teluk Jakarta. Secara umum, persepsi, pengetahuan, dan aspirasi tersebut dapat digolongkan ke 
dalam aspek-aspek sosio-kultural, sosio-ekonomi dan sosio-ekologis yang kental dengan ciri khas lingkungan urban mereka dalam konteks kota metropolitan Jakarta, akan tetapi masih menunjukkan keterikatan kuat dengan kearifan lokal nelayan tradisional pada umumnya yang berada di seluruh perairan Indonesia. Sayangnya, bentuk kearifan lokal yang khas ini sudah menunjukkan tanda-tanda kepunahan yang cukup gawat karena beratnya tekanan globalisasi dan urbanisasi yang dialami oleh masyarakat yang memilikinya. Komunitas-komunitas nelayan Teluk Jakarta karena kondisi sosial ekonominya disamakan dengan kaum miskin kota (urban poor) pada umumnya, dan dianggap sebagai sekadar bagian dari permasalahan sosial perkotaan ketimbang sektor ekonomi tradisional yang khas dan keterkaitannya dengan permasalahan perlindungan lingkungan yang krusial bagi kota Jakarta itu sendiri.

Jika kearifan lokal komunitas-komunitas nelayan yang tinggal dan mencari hidup di sana menjadi bahan pertimbangan dan bahan acuan utama, maka kebijakan dan regulasi pemerintah terkait sumberdaya alam dan lingkungan pesisir Teluk Jakarta yang paling sesuai harus menempuh strategi-strategi sebagai berikut. Pertama, satuan-satuan ekonomi tradisional masyarakat nelayan Teluk Jakarta yang belum memiliki bentuk legal formal dan oleh karena itu perlu dikukuhkan menjadi koperasi nelayan atau gabungan koperasi nelayan. Kedua, lembaga ekonomi masyarakat nelayan Teluk Jakarta harus diintegrasikan ke dalam pengelolaan infrastruktur dan tata-niaga usaha perikanan baik yang diselenggarakan oleh pemerintah maupun dunia usaha. Ketiga, bila kedua strategi tersebut di atas tidak memungkinkan maka langkah terakhir yang masih dapat dilakukan adalah membentuk "suaka laut terpadu" (integrated marine sanctuary) di Wilayah Pesisir Teluk Jakarta yang memberikan perlindungan dan pelestarian tidak saja pada lingkungan tetapi juga pada cara hidup dan penghidupan komunitaskomunitas nelayan yang tinggal di sana.

\section{Saran}

Masyarakat nelayan Teluk Jakarta harus dikembalikan perannya sebagai penjaga (steward) lingkungan sumberdaya pesisir. Akan tetapi, kapasitas institusional mereka sangat lemah dikarenakan berbagai tekanan yang mereka alami selama ini, maka yang pertama-tama harus dilakukan adalah penguatan kapasitas ekonomi. Mengingat kerangka pengaturan di tingkat nasional sudah kondusif bagi hal ini, juga dengan kenyataan bahwa nelayan pun memiliki institusi-institusi ekonomi tradisional mereka sendiri, maka langkah berikutnya adalah memberikan bentuk legal formal pada institusi-institusi tersebut. Bentuk legal formal yang dianggap paling sesuai untuk kepentingan ini adalah Koperasi. Akan tetapi, reputasi koperasi sebagai wahana pemberdayaan ekonomi sudah sedemikian rusaknya di mata nelayan Teluk Jakarta. 
Dalam rangka penguatan kapasitas ekonomi khususnya dan institusional pada umumnya, langkah berikutnya yang harus ditempuh adalah mengintegrasikan satuan-satuan ekonomi nelayan dengan infrastruktur usaha perikanan seperti pelabuhan pendaratan ikan, tempat pelelangan ikan, pasar ikan, dan sebagainya. Pendekatan yang dapat ditempuh adalah melibatkan satuan-satuan ekonomi nelayan tersebut ke dalam struktur kepemilikan atas infrastruktur-infrastruktur usaha perikanan, yang mungkin dapat dilakukan dalam kerangka kemitraan yang melibatkan pemerintah, dunia usaha, dan masyarakat nelayan. Pendekatan lainnya yang juga dapat ditempuh adalah sekadar pelibatan masyarakat nelayan dalam urusan kepengelolaan sehari-hari infrastruktur-infrastruktur usaha perikanan tersebut, meski bukan yang terideal. Kedua skala usaha perikanan itu, yaitu besar-menengah dan pengrajin-tradisional, pada kenyataannya sangat sulit untuk diintegrasikan. Sampai saat ini, hanya usaha perikanan skala besar dan menengah yang memanfaatkan infrastruktur usaha perikanan, sedangkan nelayan tradisional terpinggirkan.

Strategi terakhir yang menurut hasil penelitian ini yang paling ideal diterapkan di wilayah persisir teluk Jakarta adalah pembentukan Suatu Suaka Terpadu. Suaka terpadu ini memadukan segi lingkungan, ekonomi dan budaya dalam sebuah kawasan khusus. Dari segi lingkungan, yaitu preservasi ekosistem Teluk Jakarta; segi ekonomi, yang berarti hanya perikanan skala pengrajin dan tradisional yang dapat beroperasi di kawasan tersebut; dan, segi sosial-budaya, yaitu melestarikan cara hidup nelayan tradisional. Pilihan dari strategi ini hanya bisa dijalankan bila ada political will dari Pemerintah. Untuk mengimplimentasikan strategi ini diperlukan kehendak politik (political will) yang sangat kuat dari Pemerintah atau pemerintah lokal untuk melindungi masyarakat nelayan tradisional teluk Jakarta. Keberpihakan pemerintah atau pemerintah lokal diwujudkan dalam sebuah aturan hukum setingkat Undang-undang atau Peraturan Presiden tentang kawasan khusus suaka terpadu wilayah persisir teluk Jakarta. 


\section{Daftar Pustaka}

\section{Buku}

Berkes et Kislalioglu. "Gestion Communautaire Et Développement Soutenable.” dalam J.R. Durand, J. Lemalle, et J. Weber (ed.). La Recherche Face à la Pêche Artisanale, Symposium Internationale Orstom-Ifremer, Montpellier, France, 3-7 Juillet 1989. Paris, France: Orstom, 1991.

Cornford. "Australian Aid, Development Advocacy and Governance in the Lao PDR: Mixed Messages and Emerging Possibilities." Australian Mekong Resource Center (AMRC) Working Paper No. 1, June 1999.

Crawford, B., Balgos, M., and Pagdilao, C.R. Community-based Marine Sanctuaries in the Philippines: A Report on Focus Group Discussions. Laguna: Coastal Resources Center, University of Rhode Island, Narragansett, RI and Philippine Council for Aquatic and Marine Research and Development, 2000.

Crawford, B.R., et.al., "Community-based Coastal Resources Management in Indonesia. Examples and Initial Lessons from North Sulawesi." dalam Dwight, I., Kenchington, R., dan Baldwin, J. (eds). Proceedings of the International Tropical Marine Ecosystems Management Symposium (ITMEMS). Townsville, 23-26 November 1998.

Decoster, J., and Garcés, P.A. (eds.). Challenges Facing Artisan Fishery in the 21st Century. Bangalore: Pipal Tree, 2001.

Denzin, N.K. and Lincoln, Y.S. (eds.). Handbook of Qualitative Research, SAGE Publication Inc., 1994.

Dewan Kelautan Indonesia. Naskah Akademik National Ocean Summit. Jakarta: Sekretariat Jenderal Dewan Kelautan Indonesia, tanpa tahun.

Eghenter, C., Sellato, B., and Devung, G.S. (Ed.). Social Science Research and Conservation Management in the Interior of Borneo, Unravelling Past and Present Interaction of People and Forest. Bogor: Center for International Forestry Research (CIFOR), 2003.

Harsono. Hukum Agraria Indonesia, Sejarah Pembentukan UndangUndang Pokok Agraria, Isi, dan Pelaksanaannya. Jilid 1 Hukum Tanah Nasional. Edisi Revisi. Jakarta: Djambatan, 2003

Jhingan. Ekonomi Pembangunan dan Perencanaan. terj. D. Guritno. Jakarta: RajaGrafindo Persada, 1996.

Kusnadi. Akar Kemiskinan Nelayan. Cet. I. Yogyakarta: LkiS, 2003. 
Kusnadi. Konflik Sosial Nelayan, Kemiskinan dan Perebutan Sumberdaya Alam. Yogyakarta: LKiS, 2006.

Loxley. "Aboriginal Economic Development in Winnipeg." dalam Silver (ed.). Solutions That Work. Fighting Poverty in Winnipeg. Winnipeg: Canadian Centre for Policy Alternatives, 2000.

Mulyadi. Ekonomi Kelautan. Edisi I. Jakarta: Radja Grafindo Persada, 2005.

Mulyadi. Ekonomi Kelautan. Jakarta: RajaGrafindo Persada, 2005.

SEAFDEC. Regional Guidelines for Responsible Fisheries in Southeast Asia. Fisheries Management. Bangkok: Southeast Asian Fisheries Development Center (SEAFDEC), 2003.

Solihin et.al. Strategi Pembangunan Kelautan dan Perikanan Indonesia (Bunga Rampai). Bandung: Humaniora, 2005.

Todaro. Economic Development (5th ed.). New York: Longman, 1994.

White, A.L., et.al. "Integrated Coastal Management in Philippine Local Governance: Evolution and Benefits." dalam Krishnamurthy, R.R., et.al. (eds), Integrated Coastal Zone Management. Singapore: Research Publishing Services, 2008.

Yasni. Bung Hatta's Answer, an Interview with Bung Hatta. Singapore: Gunung Agung, 1981.

\section{Disertasi}

Breunig. "Conservation in Context: Establishing Natural Protected Areas During Mexico's Neoliberal Reformation”, Ph.D. Dissertation. University of Arizona, Department of Geography and Regional Development, 2006.

Soto, C.G. "Socio-Cultural Barriers to Applying Fishers' Knowledge in Fisheries Management: An Evaluation of Literature Cases", Ph.D Dissertation in the School of Environmental Management Simon Fraser University, Burnaby, BC, Canada, 2006.

\section{Makalah dan Artikel}

"Akhirnya Jalan Juga. Pemkot Bangun TPI Dilengkapi PPI, Pasar Induk, dan Rusunawa", Jawa Pos. <http://www2.jawapos.co.id/ metropolis/index.php?act=detail\&nid=35476>, diakses tanggal 9 Juli 2007.

"Bakau di Angke Rusak, Peserta Mangrove Challenge Tanam Lebih dari 1100 Pohon", Kompas, <http://www2.kompas.com/kompascetak/0707/09/metro/3674115.htm>, diakses tanggal 9 Juli 2007. 
"Hutan Bakau di Pantai Jakarta Tinggal 27 Persen", Kompas, $<$ http://www2.kompas.com/kompas-cetak/0305/19/metro/316249. htm>, diakses tanggal 19 Mei 2003.

"Meningkatkan Kesejahteraan Melalui Sektor Kelautan", Suara Merdeka, <http://www.suaramerdeka.com/harian/0503/28/ pan14.htm>, diakses tanggal 28 Maret 2005.

"Mestinya Pilar PAD Setelah Pertanian dan Industri, Sektor Perikanan Belum Tergarap", Pikiran Rakyat, <http://www.pikiranrakyat.com/prprint.php?mib=beritadetail\&id=63099>, diakses tanggal 6 April 2009.

"Nelayan Belum Diberdayakan", Kompas, <http://cetak.kompas.com/ $\mathrm{read} / \mathrm{xml} / 2009 / 04 / 06 / 03423382 /$ Nelayan.Belum.Diberdayakan>, diakses tanggal 6 April 2009.

"Nelayan Brebes Minta Pemerintah Bangun Infrastruktur Perikanan", Harian Umum Sore Sinar Harapan, No. 4089, <http://www.sinarharapan.co.id/berita/0409/22/eko08.html>, diakses tanggal 22 September 2004.

"Nelayan dan Bakul Minta Jaminan Keamanan, Jelang Operasionalisasi PPI Tambaklorok", Suara Merdeka, <http://www.suaramerdeka .com/harian/0701/22/kot01.htm>, diakses tanggal 22 Januari 2007

"Pesisir Jakarta, Menata Timbunan Masalah Dengan Masalah", Rieska Wulandari, National Geographic Indonesia, Juli 2008.

"Reklamasi Mulai 2009. Jakarta Utara Perlu Banyak Pembenahan", Kompas, 15 April 2009. <http://cetak.kompas.com/read/xml/2009/ 04/15/03525394/reklamasi.mulai.2009>, diakses tanggal

"Asal usul nama tempat di Jakarta", http://www.budayajakarta.com/dload/pic/aunj.pdf.

"Bisnis Pesisir Anti-Rentenir", dalam Gatra Edisi Khusus, Di Laut Kita Belum Jaya, (Januari 2006).

"Pacu Pengembangan Tiga Komoditas Unggulan", $<$ http://www.wirausaha.com/berita/396-pacu_pengembangan_tiga_ komoditas_unggulan.html>, diakses tanggal

"Sebanyak 22 koperasi perternakan dan perikanan di Jakarta Utara dinyatakan tidak aktif pengelolaannya", <http://www.jakartautara .com $/$ modules/news/article.php?storyid $=6148>$, diakses tanggal

"Selayang pandang Kota Jakarta Utara", <http://perencanaanjakut.org/spandang.htm>, diakses tanggal

Adrianto. "Agenda Makro Revitalisasi Perikanan yang Berkelanjutan", Majalah Inovasi Vol.6 (XVIII/Maret 2006) 
. "Implementasi Code of Conduct for Responsible Fisheries dalam Perspektif Negara Berkembang", Jurnal Hukum Internasional, Volume 2 (Nomor 3, April 2005).

Arifin, Z. Local "Millenium Ecosystem Assessment: Condition and Trend of the Greater Jakarta Bay Ecosystem", Jakarta: The Ministry of Environment, Republic of Indonesia, 2004.

Armstrong. "Just Fishing? Equity and Efficiency in Fisheries Management Regimes", Journal of Marine Resource Economics, Volume 12 (1997).

Ben-Yami, M. "Hijacked by Neoliberal Economics", Samudra Report No. 35 (July 2003).

Escobar, A. "Whose Knowledge, Whose Nature? Biodiversity Conservation and the Political Ecology of Social Movements", Journal of Political Ecology Volume 5 (1998).

Friends of the Earth (FOE) International. "Nature: Poor People's Wealth", Position paper by Friends of the Earth International for the UN World Summit and the Review of the Millennium Development Goals 14 - 16 September 2005.

Kerkhoff, L.v. and Lebel, L. "Linking Knowledge and Action for Sustainable Development", Annual Review of Environment and Resources Volume 31 (2006).

Kusnadi. "Upaya Meningkatkan Kesejahteraan Nelayan Jatim, Solusi Diversifikasi Usaha Non-perikanan tidak Semudah Membalikkan Telapak Tangan. (Tanggapan untuk Tulisan Bagong Suyanto dan Edi Susilo)", Harian Kompas Jawa Timur, 6 Mei 2003. http://www2.kompas.com/kompas-cetak/0305/06/jatim/295265.htm.

Mutunga. "The Problem of Open Access in an Unregulated Common Property: The Case of Kenya's Lake Victoria Fisheries", Paper presented at the Beijer International Institute for Ecological Economics Research Seminar, Durban, South Africa 28-30 May 2002.

Parras, D.A. "Coastal Resources Management in the Philippines: A Case Study in the Central Visayas Region", Journal of Environment and Development, Vol. 10 (No. 1, March 2001).

Pirttijärvi, J. "Indigenous Peoples and Development in Latin America", Swedish School of Social Science, University of Helsinki, SSKH Reports and Discussion Papers 6/98.

Salam, M.A., Ross, L.G., and Beveridge, M.C. "Ecotourism to Protect the Reserve Mangrove Forest in Sundarbans and its Flora and Fauna", Anatolia 2000. 11 (1). 
Schmidt. "Fisheries and Japan: A Case of Multiple Roles?", Paper prepared for the International Symposium on Multiple Roles and Functions of Fisheries and Fishing Communities, 13 February 2003, Aomori, Japan.

Skonhoft. "Modern Fishing Technology and Profitability in a Second Best Situation", Norwegian University of Science and Technology Department of Economics Working Paper Series No. 6/ 2007.

Soenarno, "Pemberdayaan Wanita Nelayan Melalui Pendidikan", Program Studi Pengelolaan Sumber Daya Alam dan Lingkungan Program Pascasarjana IPB.

Soetrisno. "Wajah Koperasi Tani dan Nelayan di Indonesia: Sebuah Tinjauan Kritis", Jurnal Ekonomi Rakyat Tahun II (Nomor 5 Agustus 2003). <http://www.ekonomirakyat.org/edisi_17/ artikel_4.htm>, diakses tanggal 14 Januari 2004.

Soumya and Shah. "Briefing Paper on Fisheries Policy: Resources Rights of Individual Communities", Paper presented in Terracotta Summit: Beyond NEP 2004: Institutions, Incentives, and Communities, New Delhi, 7 Maret 2005.

Swasono. "Indonesia is Not for Sale: Sistem Ekonomi Nasional untuk Sebesar-besar Kemakmuran Rakyat”, Makalah disampaikan dalam Rapat Kerja Terbatas Kelompok Kerja Khusus Dewan Ketahanan Nasional, 20-21 November 2007.

Tall. "World Trade Trends for Fishery Products and the Share of Africa", Infopeche Trade, March (2002).

Torell, M. and Salamanca, A.M. (Ed.). "Institutional Issues and Perspectives in the Management of Fisheries and Coastal Resources in Southeast Asia", ICLARM Technical Report 60, Bayan Lepas, Penang: ICLARM and SIDA, 1997.

Trebilcock. "Critiquing the Critics of Economic Globalization", Journal of International Law and International Relations. Volume 1 (No. 2, 2004).

Walter, E. "Fishing Around the Law: The Pacific Salmon Management System as a "Structural Infringement" of Aboriginal Rights", McGill Law Journal Volume 45 (2000).

Yamamoto. "Collective Fishery Management Developed in Japan, Why Community-Based Fishery Management Has Been Well Developed in Japan?", IIFET Proceedings (2000).

\section{Peraturan Perundang-Undangan}

Food and Agriculture Organization of the United Nations (FAO), Code of Conduct for Responsible Fisheries. 
United Nations Declaration on the Rights of Indigenous Peoples.

Indonesia, Kepmen Kelautan dan Perikanan Nomor: KEP.18/MEN/2002 tentang Rencana Strategis Pembangunan Kelautan dan Perikanan Tahun 2001-2004.

. Permen Kelautan dan Perikanan No.PER.17/MEN/2006 tentang Usaha Perikanan Tangkap.

. Perpres Nomor 77 Tahun 2007 tentang Daftar Bidang Usaha yang Tertutup dan Bidang Usaha yang Terbuka dengan Persyaratan di Bidang Penanaman Modal.

. Tap MPR Nomor XV/MPR/1998 tentang Penyelenggaraan Otonomi Daerah; Pengaturan; Pembagian, dan Pemanfaatan Sumber Daya Nasional, yang Berkeadilan; Serta Perimbangan Keuangan Pusat dan Daerah dalam Kerangka Negara Kesatuan Republik Indonesia.

. Undang-Undang Dasar 1945.

. UU Nomor 1 Tahun 1960 tentang Penetapan Perpu Nomor 19 Tahun 1960 tentang Perusahaan Negara sebagai UndangUndang.

. UU Nomor 19 Tahun 1969 tentang Perpu Nomor 1 Tahun 1969 Tentang Bentuk-Bentuk Usaha Negara sebagai UndangUndang.

Negara.

. UU Nomor 19 Tahun 2003 tentang Badan Usaha Milik

. UU Nomor 25 Tahun 2007 tentang Penanaman Modal.

. UU Nomor 27 Tahun 2007 tentang Pengelolaan Wilayah Pesisir dan Pulau-pulau Kecil.

. UU Nomor 31 Tahun 2004 tentang Perikanan.

. Keputusan Presiden No. 52 Tahun 1995.

. Perda DKI Jakarta No. 8 Tahun 1995.

. Keputusan Gubernur DKI Jakarta No. 972 Tahun 1995.

. Keputusan Gubernur DKI Jakarta No. 1090 Tahun 1996.

. Keputusan Gubernur DKI Jakarta No.138 Tahun 2000.

2003.

. Keputusan Menteri Lingkungan Hidup Nomor 14 Tahun

. Peraturan Presiden (Perpres) No. 54 tahun 2008.

. UU Nomor 5 Tahun 1960 tentang Peraturan Dasar PokokPokok Agraria. 
United Nations, Agreement for the Implementation of the Provisions of the United Nations Convention on the Law of the Sea of 10 December 1982 Relating to the Conservation and Management of Straddling Fish Stocks and Highly Migratory Fish Stocks 1995. . Convention on the Law of the Sea 1982. 